\title{
Operating Performance of Public Banks in Taiwan after Privatization
}

\author{
*Z-John Liu'1 ${ }^{1}$ Justine Chang² \\ ${ }^{1}$ Ling Tung University, Taiwan \\ ${ }^{2}$ Chaoyang University of Technology, Taiwan \\ *liuzjohn@gmail.com
}

\begin{abstract}
The study selected nine state-owned banks in Taiwan that went on privatization in 1998 and foreign banks with similar assets scales and more branches in Taiwan as sample. Data Envelopment Analysis (DEA) is applied to explore the variation condition of efficient values for the periods between 1995 and 2007, prior and after each state-owned bank became privatized. To avoid data bias, the years affected by financial storm (from 2008 to 2010) were eliminated. Empirical results of the study are: The number of branches and assets return ratio are positively correlated to overall technical efficient value; savings and government holding ratio are negatively correlated to overall technical efficient value, showing that government releasing stock holdings through privatization can actually improve bank operating efficiency. The result of MannWhitney non-parametric examinations show that: Before the state-owned banks in Taiwan privatized, their average operating efficiency is significantly lower than that of foreign owned banks. After privatization, there is no significant difference in operating efficiency between state-owned and foreign-owned banks, revealing that privatization has effect of enhancing operating efficiency in public banks.
\end{abstract}

Keywords: Privatized banks, operating efficiency, DEA

\section{Introduction}

In facing the growing trend of globalization and following the promotion of regional economic organization of World Trade Organization (WTO), every nation went on to lift all kind of monetary limitation one after another to increase internationalization and financial liberalization. As such, cross-national operations and competition in financial industry will be more intense. In a nation's economic development process, stateowned banks and businesses elaborate effects of stabilizing financial market and economic condition. In competitive markets, there is a presumption in private ownership. Where there is a natural monopoly, vigorous regulatory action is required. The evidence suggests that privatization has led to improved performance by firms such as the National Freight Corporation, Cable, and Wireless, which operate in a relatively competitive environment (Yarrow, 1986). Under the impact of global financial liberalization, every nation has actively promoted privatization of state-owned business. Back then, the Prime Minister of the United Kingdom, Madam Thatcher, advocated lowering operating limitation and emphasized full autonomy of market economy to allow market bringing free competitive mechanism into full play. During Madam Thatcher's term in office (from 1979 to 1987), the total value of state-owned business stocks sold averaged 1 billion pounds annually (Chen, 2004) and operating performance of state-owned business was enhanced, such as Jaguar, which profit increased 33\% one year after privatization. The study of Mahboobi (2000) found that there are approximately 80 nations promoting policy of privatize state-owned business like wildfire that even many communist nations have followed suit.

The financial industry in Taiwan also faces challenge of international financial market after its door opening. Since 1961 when the government of Taiwan officially opened door to foreign banks to establish branches in Taiwan, from 2002 to 2009, the numbers of branches have increased from 68 to 133, among which the numbers have reached to 143 once. (Central Bank, 2010) The branches have grown nearly doubles. Taiwan also passed modified regulations in April 4, 2007 to allow foreign financial institutions that have not yet established subsidiary or branch in Taiwan to participate in public bank bidding in Taiwan and an establish subsidiary after they get the bid. The promulgation of such law greatly increases operation of foreign banks to participate in merging financial institutions in Taiwan. Thus, through international merger and acquisition not only can operating efficiency be enhanced but also promoting financial internationalization in Taiwan and competitive challenges. The rapid development of foreign banks in Taiwan generates huge impact on 
operating system of state-owned banks in Taiwan. State-owned banks with old traditional stabilizing power face great challenges. Thus government must seriously consider whether similar policy should change tracks, and through various stocks releasing methods to let state-owned banks heading toward privatization, introducing professional and advanced operating method of private business to increase operating performance of state-owned banks under international competitive mechanism. Regardless of market transformation mechanism or policy promotion, state-owned banks are gradually transformed to profit oriented private banks in order to combat outside competitors that rush in, prepared.

Foreign banks usually are more flexible than domestic banks in operating range and products development. In addition to general business and personal loans, foreign banks are leaders of innovation in consumptive credit cards and loans. With their experience and advantage in conglomerate global assets management, the foreign banks' development and marketing in financial investment products and derivative investing instruments are all better than operating effects of domestic state-owned banks. Take example of overall earnings of Taiwan banks in 2005, earnings of domestic banks were 78.641 billion NTD, while foreign banks achieved 20.083 billion NTD, which is $25.54 \%$ of the earnings of domestic banks. However, the total branches of foreign banks only constituted $2 \%$ of total banks in Taiwan. Thus, state-owned banks must face competition from foreign banks seriously. The threat of foreign banks in operations also reflects that under competition of international financial environment, the importance of promoting privatization of state-owned banks to strengthen operating performance. To examine the developing condition in privatization of stateowned businesses in Taiwan (as shown in Table 1), industry with the highest numbers and ratios of transfers to private business is banking industry, taking $21.4 \%$ of overall privatized industries, $(\mathrm{Wu}, \mathrm{Sun}$, Hong, and Lee, 2004) which demonstrates the effects of state-owned banks in privatization and, at the same time, it also impacts development of economic environment in Taiwan. Because the effect and impact generated by banking industry is huge to national macro economy, whether the developing process of financial institutions privatization is good and sound should be the problem that the public must be concerned and explore. Therefore, to examine whether state-owned banks in Taiwan can effectively increase their operating performance and efficiency after privatization and compare the difference between state-owned banks after privatization and foreign banks in operating efficiency are the main theme to be analyzed and explored further in this study.

Table 1: Numbers and ratios of state-owned business transferred to private sectors

\begin{tabular}{|c|c|c|}
\hline Industry & Ratio & Privatized companies \\
\hline Banking & $21.4 \%$ & $\begin{array}{l}\text { Chang Hwa Bank, First Bank, Hwa Nan Bank, Taiwan Business Bank, } \\
\text { Farmers Bank, Kaohsiung Bank, Taipei Bank, Cooperative Bank, Chiao } \\
\text { Tung Bank }\end{array}$ \\
\hline Insurance and trust & $11.9 \%$ & $\begin{array}{l}\text { Chung Kuo Insurance Co., Ltd., Taiwan Fire and Marine Insurance Co. } \\
\text { Ltd., Taiwan Life Insurance Co., Ltd., Taiwan Land Development } \\
\text { Corporation, Central Reinsurance Corporation }\end{array}$ \\
\hline Steel and iron & $11.9 \%$ & $\begin{array}{l}\text { China Steel Corporation, Taiwan Machinery Steel Company, Taiwan } \\
\text { Machinery Alloy Steel Company, Tang Eng Steel Company, Tang Eng Iron } \\
\text { Works Co., Ltd., }\end{array}$ \\
\hline Transportation & $11.9 \%$ & $\begin{array}{l}\text { Yang Ming Marine Transport Corp., Taiwan Navigation Co., Ltd., Taiwan } \\
\text { Motor Transport Co., Ltd., Tangeng Advanced Vehicles }\end{array}$ \\
\hline Electrical mechanics & $9.4 \%$ & $\begin{array}{l}\text { Taiwan Machinery Marine Company, Gangshan Company, Taiwan } \\
\text { Machinery Manufacturing Corp., Taiwan Provincial Agriculture and } \\
\text { Machinery Corp. }\end{array}$ \\
\hline Petroleum & $7.1 \%$ & $\begin{array}{l}\text { CPC Corp., Liquefied Petroleum Gas Supply Plant, Veteran Gas } \\
\text { Manufacturing Plant }\end{array}$ \\
\hline Che & & Taiwan Fertilizer Co., Ltd., Taiyen Corp. \\
\hline Auts & $4.8 \%$ & Tangeng Road Vehicles Department, Taneng Rail Vehicles Dep \\
\hline Press a & $4.8 \%$ & Taiwan Shin Sheng Daily News, Taipei City Printing \\
\hline Construction & $2.4 \%$ & BES Engineering Corp., ChungHsing Paper Corp. \\
\hline
\end{tabular}

Source: Council for Economic Planning and Development, the Executive Yuan. 


\section{Literature Review}

Effect of state-owned business privatization: Privatization usually leads managers to place greater emphasis on the pursuit of profits. However, whether this is beneficial to society depends on the trade-off between possible market failures due to a lack of competition and deficiencies in government control of public firms. The competitive and regulatory environment is more important than the question of ownership per se (Yarrow, 1986). Sueyoshi (1998) used Japanese Telephone Company that went on privatization in 1985 as study example and applied DEA model to analyze the company's productive performance after privatization. Results of study show that there is a positive elevating effect on productivity generated in Japanese Telephone Company after privatization, which was mainly due to the decrease in numbers of employees. Sueyoshi's study also suggested that the government should reduce her control on businesses so they can achieve effect of free market operations. Wei, et al. (2003) explored the financial and operating performance of 208 Chinese companies before and after privatization for period between 1990 and 1997 and applied financial ratio method for analysis. Results of study find that companies' actual output, assets and sales efficiency showed significant elevation and financial leverage lowered, showing positive fruitful result of efficient feedback of privatization in China.

In examining other studies in performance of global privatization, D'Souza, et al. (2005) focused on 23 nations in OECD and took 129 companies for performance analysis in privatization by using regression analysis to explore data of the period between 1961 and 1999. Results of study showed that profit and operating efficiency both increased after privatization and when every employee's productivity was elevated, there was no significantly reduction in employment rate. Tsamenyi et al. (2008) applied the five face dimensions of balance score card to measure performance of two computer and law offices in Ghana after privatization. The empirical results pointed out that the overall performance of both privatized companies was improved. To summarize the aforesaid studies, there is actually an effect of elevating operating performance and productivity in privatization of state-owned businesses.

Although many literatures pointed out positive effect in performance of privatization, there are also opposite views. Martin and Parker (1995) studies 11 stated-owned businesses in England that went on privatization in period between 1981 and 1988 and the results of their study showed that in more than half of the companies that went on privatization, their return on assets and growth ratio of every employee's added value did not show better result. Uddin and Hopper (2003) used financial ratio analysis method to study performance of privatization in Bangladesh and results of their study found that among 11 sample companies of privatization, there was only one that showed growth in financial ratio while all the other companies had decreased financial ratio. Their study also pointed out the reduced ratio of social feedback and contribution to nation's finance in companies after privatization, causing the drop in financial transparency and employment conditions, thus largely lowering companies' operating performance.

Studies in privatization of state-owned banks in Taiwan: Teng (2002) examined difference between domestic and foreign owned banks in operating performance for the year 2001 and result of his study pointed out: The operating performance of domestic banks were far below the one of branches of foreign-owned banks in Taiwan. The overall overdue loan ratio of foreign-owned banks are only half of the one of domestic banks while stockholder's equity return ratio of foreign-owned banks are approximately 9 times that of domestic banks. Domestic banks rely mostly on interests as major source of income while foreign-owned banks often raise service fees and commission income as major source of revenue. Lin (2003) studies 24 state-owned and private banks for two periods between 1995 and 1997 and 2000 and 2002 by using input items of interest expense, personnel expense and net worth and output items of interest revenue and noninterest revenue and applied DEA for analysis. Results of study showed that: During this six-year period, operating efficiency dropped steadily, mainly due to inefficient scale. In addition, for the three years before and after state-owned banks privatized, private banks had the highest overall efficient value.

Chiang (2004) studied a bank from years 1997 to 1998 and 2000 to 2003, the six years before, after the bank privatized, and used DEA for analysis. Results of study showed that: The reason for the case bank's operating inefficiency is inefficient scale and there was no significant change of operating efficiency before and after the bank privatized. Chen (2005) studied 70 branches of a bank from years 1997 to 1999 and 2003 to 2005, the 
six years before, after the bank privatized, and used DEA for analysis. Results of study showed that: The technical average value of the case bank is 0.695 , in which pure technical efficiency is 0.761 and scale efficiency is 0.9165 . The overall operating efficiency of bank was not elevated by privatization. Studies in privatized state-owned banks in Taiwan mostly explored case bank and nearly no focusing on all privatized banks in Taiwan, compared separate banks the difference in efficiency of different years before and after privatization, did not explain variables choices, mostly used only DEA for analysis and did not add Malmquist Productivity Index and Tobit Regression. To summarize the aforesaid literature findings, most researchers applied data envelopment analysis to explore relative efficiency of different decision making units in the same period and further used Malmquist Productivity Index to analyze cross-periods study of different decision making units, then used regression model to examine extent of correlation on effect of input variables and efficient value. The study aims to further applied non-parametric statistics to explore difference in operating efficiency between privatized state-owned banks and foreign-owned banks in Taiwan.

Data envelopment analysis in evaluating banks' performance: Sherman and Gold (1985) were the first scholars that applied DEA in bank efficiency evaluation. They studies fourteen branches of a bank in 1980 and used CCR model of DEA for analysis. Results of study showed: 1. High cost does not necessarily cause inefficiency. 2. Six branches are relatively inefficiency, thus can decrease input or increase output to elevate efficiency. Sathye (2001) focused on 29 banks in Australia as sample and used DEA, ANOVA analysis and regression analysis to evaluate efficient value. Results of the study found: 1 . the source of inefficiency in Australian banks are because of too much input (technical inefficiency), not inappropriate input combination. (Allocation inefficiency) 2. Domestic banks have relatively higher efficient value than their foreign counterparts. 3. Regression analysis showed that savings factor has significantly negative effect on efficient value.

Drake and Howcroft (2002) studied 190 branches of a large liquidating bank in England and used DEA, relativity analysis and Tobit regression for analysis. Results of study were: 1 . Source of inefficiency mainly comes from inefficiency in pure techniques. 2. There were negative correlation in size of branches and scale efficiency and size of branches and total technical efficiency. 3. Technique and managerial control have significant positive effect on efficient value while products variety has significantly negative effect on efficient value. Drake and Hall (2003) explored efficiency of 149 banks in Japan in 1997. They used general expense plus administrative expense, fixed assets and deposit as input items, total loans plus discounted notes receivable, current assets plus securities investment and other revenues are output items, and analyzed via DEA. Results of study showed: The reason of inefficiency in entire bank comes from inefficiency in pure technique, not inefficiency in scale. Long-run credit loan banks and credit loan banks are efficient banks. Overdue loan significantly affect operating efficiency value.

Mostafa (2007) explored top 100 banks in Arab in 2005 by analyzing 85 banks, which remained after deducting 15 of noncompliant conditions, with capital and assets as input items and net worth, stockholders' return on equity and return on assets as output items, via DEA. Results of study were: 1 . Average value of overall technical efficiency is 0.31 . Average value of pure technical efficiency is 0.43 . Most evaluated units are in increasing scale returns. 2. Model stability is good. Hu, et al. (2009) evaluated operating performance of 14 financial control companies in Taiwan via DEA, Bilateral, SBM and FDH for analysis. Results of study were: 1. Non-efficient banks mostly come from technical problems. 2. FDH has no differentiating power on efficient value. 3. Bilateral obtained that financial control companies based on non-banks have higher efficient value than the one based on banks.

\section{Methodology}

DEA Model: CCR model was established by Charnes, Cooper and Rhodes in 1978, used in evaluating relative efficiency of decision making units under fixed scale returns. Its relative efficiency is also called total technical efficiency. CCR model can evaluate efficiency value either from input-oriented or output-oriented. Input-oriented is to measure and compare usage condition in input resource under the same output level while output-oriented is to measure and compare output condition under the same input level. Management in banking industry controls their input resources more easily, thus the study chose input-oriented. BCC model was established by Banker, Charnes and Cooper in 1984 to expand CCR model, used in evaluating 
relative efficiency of decision making units under variable scale returns. Its relative efficiency is also called pure technical efficiency. Total technical efficiency divided by pure technical efficiency can obtain scale efficiency. BBC model can also measure efficiency value either from input-oriented or output-oriented. The study chose input-oriented for analysis due to the same reason described in choosing CCR model.

Malmquist productivity index: Malmquist productivity index (MPI) is used to compare changes in productivity of different banks cross-periods. It can be separated to technical efficiency change and technique change, of which technical efficiency change represents the extent that technical efficiency of a decision making unit increase or decline while technique change represents the changing condition of different efficiency margin in two periods. Technical efficiency change, under fixed scale returns, can be divided to pure technical efficiency change and scale efficiency change of variable scale returns.

Tobit regression model: Because the efficiency value obtained by CCR and BCC models are between 0 and 1 , in order to understand reasons that affect efficiency value, the study applied truncated Tobit regression model for analysis. Nobel Prize in Economics Laureate Tobin (1958) proposed the original Tobit regression model for limited dependent variables. In the model, the dependent variable is between 0 and 6 . The distribution of the data is different from general regression model, using ordinary least square to estimate regression coefficient would result in bias. Thus, maximum likelihood method was used to estimate. (Amemiya, 1973) Goldberger (1964) modified the original Tobit regression model and called it truncated Tobit regression model. The original Tobin regression model was then called censored dependent variables Tobit regression model for distinction. The original Tobit regression model is as follows:

$$
\begin{aligned}
& y_{i}^{*}=x_{i} \beta+\varepsilon_{i}, \varepsilon_{i} \sim N\left(0, \sigma^{2}\right) \\
& y_{i}=y_{i}^{*} \text { if } y_{i}^{*}>0 \\
& y_{i}=0 \text { if } y_{i}^{*} \leq 0 \\
& \quad \text { Where as } \\
& y_{i}^{*} \text { Represents sample observation value. } \\
& y_{i} \text { Represents dependent variables after truncation from Tobit regression. } \\
& x_{i} \text { Represents independent variable. } \\
& \beta \text { Represents coefficient value of variable. } \\
& \varepsilon_{i} \text { Represents error. }
\end{aligned}
$$

The original Tobin model is a censored regression model, which treats every sample observation value as occurred or non-occurred events. Occurred events can treat random variables as continuous and positive. On the contrary, non-occurred events will treat variable as zero value.

Mann-Whitney non-parametric examination: The study applied DEA model to obtain operating efficiency value of privatized state-owned banks and foreign owned banks. Because DEA used mathematical planning to obtain efficient frontier value, there is no need to preset function of input and output items, and no need to estimate coefficients of function. The study would further explore difference in efficiency value between the two groups of privatized state-owned banks and foreign-owned banks, thus applying Mann-Whitney nonparametric examination method that is appropriate for both groups. Mann-Whitney non-parametric examination was proposed by Borckett and Golany (1996) to test efficiency orders of DEA. It aims to examine whether there is difference in average efficiency value between two groups, meaning to test whether the DEA efficiency value of two independent groups, such as privatized state-owned banks and foreign owned banks in Taiwan, is the same distribution. The two groups were combined first, and then were ranked according to efficiency value. The same efficiency value would use average of connecting rank as rank value and compute ranking position and rank sum of two groups. T value was computed as follows:

$$
\text { Or } \begin{aligned}
T & =n_{1} n_{2}+\frac{n_{1}\left(n_{1}+1\right)}{2}-w_{1} \\
T & =n_{1} n_{2}+\frac{n_{2}\left(n_{2}+1\right)}{2}-w_{2}
\end{aligned}
$$


Whereas $w_{1}$ represents rank sum of Group $\mathrm{A}$ and $w_{2}$ represents rank sum of Group A. When the examined sample is small, $\left(n_{1} \leq 10, n_{2} \leq 10\right)$ the selection method of examined statistics is as follows:

$T=\min \left(T_{1}, T_{2}\right)$

When two groups are large samples, $\left(n_{1} \geq 10, n_{2} \geq 10\right) \mathrm{T}$ is closing average value $n_{1} n_{2} / 2$ and variables are normally distributed $n_{1} n_{2}\left(n_{1}+n_{2}+1\right) / 12$, it follows the $\mathrm{Z}$ standard distribution as follows:

$$
Z=\frac{U-n_{1} n_{2} / 2}{\sqrt{n_{1} n_{2}\left(n_{1}+n_{2}+1\right) / 12}}
$$

To summarize the above, under significant level of $\alpha$, if $Z \leq Z_{\alpha / 2}$ or $Z \geq Z_{1-\alpha / 2}$, null hypothesis is rejected. Statistical examination obtained result that there is significant variance between efficiency values of the two groups.

\section{Results}

DEA empirical analysis and comparison: Through DEA analysis on efficiency value of privatized stateowned banks, the empirical result is that total technical efficiency value of Chang-Hwa Bank, First Bank, HwaNan Bank, Chiao Tung Bank, Kaohsiung Bank and Cooperative Bank is significantly higher than the one before privatization. Take the changes in operating efficiency value of Chiao Tung Bank during privatization as example, with privatization basis of year 1999 as dividing point; the average total technical efficiency value for period from 1995 to 1998 is 0.6335 , which is far lower than the average efficiency value of 0.974 for the years from 1999 to 2005. It proved that privatization of Chiao Tung Bank has significant effect on elevating overall operating efficiency. In addition, among the nine privatized state-owned bank sample explored in this study, there were six banks that have better average efficiency value performance after the basis year of privatization.

In the part of analyzing total technical efficiency value of Taiwan Business Bank, Taipei Bank and Farmers Bank, although the changes in operating efficiency value of the three privatized state-owned banks are more volatile, through change analysis in total technical efficiency value, we can find that there is significant elevating effect in operating efficiency after privatization. Take Taiwan Business Bank as example. The total operating efficiency value of Taiwan Business Bank in two years after privatization is better than the one before privatization. The efficiency value started to change in the third year after privatization, in which efficiency value for the years 2001 and 2005 are lower than the one before privatization. However, the total technical efficiency value significantly bounced back in the year after 2001 and 2005. In 2005, the total technical efficiency value of Taiwan Business Bank only reached 0.579. Through privatization, that has effect in promoting operating efficiency; in the following year 2006, the total technical efficiency value of Taiwan Business Bank has risen to 1.000. The growth extent of total technical efficiency in the first three years of privatizing Taiwan Business Bank is relatively slow, for the two years from 1995 to 1997, the total technical efficiency value only rose 0.121 . Overall, privatization has effect of elevating operating efficiency of stateowned bank, in compliance with the objective of Taiwanese government in dedicatedly pushing state-owned banks to privatization.

Malmquist productivity index analysis: From Malmquist productivity index line chart (Figure 1) we can see that the year 2001 appears to decline in comparing to the year 2000. There were five banks with efficiency value lower than 1 while the average Malmquist productivity index is 0.992 . The 911 terrorists attack in 2001 caused global economic loss of 350 billion US dollars. It was the first time in 40 years that the economic growth rate in Taiwan became negative, in which the impact on financial industry is more severe. In comparing to year 2001, Malmquist productivity changes in 2002 also appeared to decline, with average value dropping to 0.957 . The dropping productivity in l banks was mostly due to decline in technical efficiency. For the two periods of years from 2002 to 2003 and 2003 to 2004, Malmquist productivity index were in growing trend, in which the average value of 1.77 for years from 2002 to 2003 was the best efficiency performance of privatization. However, the break out of global SARS epidemic starting from the second half of 2003 and avian 
flu in 2005 had discouraged people going to public places. Consumption power in every nations suffered severe negative impact, consequently worsening of macro-economic environment in our nation. That is one of the main reason that Malmquist productivity index of every banks from second half of 2003 to 2005 appeared to decline. From Malmquist productivity index analysis we also found that Kaohsiung Bank and Chiao Tung Bank were two privatized state-owned banks that had most stable growth after privatization, in which Kaohsiung Bank had growth performance of Malmquist productivity index larger than 1 in five crossperiods.

For the average Malmquist productivity of every privatized state-owned banks, except Taiwan Business Bank that had average value little lower than 1 and appeared to decline, all the remaining sample banks: Chang Hwa Bank, First Bank, Hwa Nan Bank, Farmers Bank, Kaohsiung Bank and Taipei Bank all had growth performance in the six years period, among which Taipei Bank was the best, with average Malmquist productivity index of 1.309 .

\section{Figure 1: Malmquist Productivity Index}

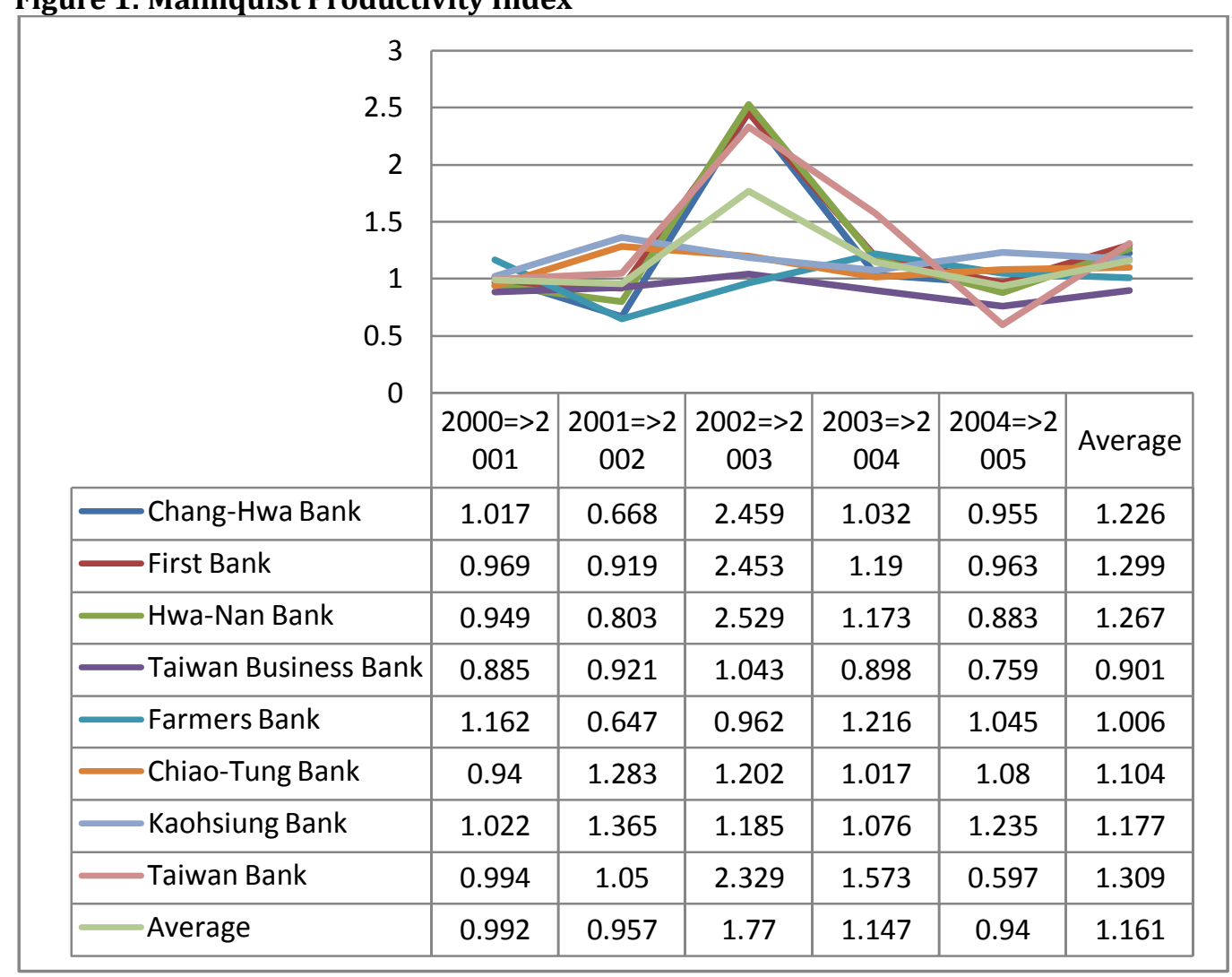

Tobit regression analysis: The study used DEA model analysis to obtain efficiency value between 0 and 1 of every privatized state-owned bank. From empirical Tobit regression result we can see that number of branches has significant effect on operating efficiency value of privatized state-owned banks. After stateowned banks privatized, they can establish more branches to satisfy people's need and convenience, thus elevating operating efficiency of privatized state-owned banks. 
Table 2: Tobit Regression Analysis Result

\begin{tabular}{llll}
\hline & Independent variable & Coefficient & P-value \\
\hline $\mathrm{C}$ & Constant & 2.16386 & $0.0000^{* * *}$ \\
$X_{1}$ & ATM volume & $8.49 \mathrm{E}-06$ & 0.9189 \\
$X_{2}$ & log(Deposit) & -0.16498 & $0.0062^{* * *}$ \\
$X_{3}$ & Cost per employee & $9.35 \mathrm{E}-06$ & 0.5497 \\
$X_{4}$ & Number of branches & 0.00092 & $0.0407^{* *}$ \\
$X_{5}$ & Capital adequacy ratio & 0.00838 & 0.0867 \\
$X_{6}$ & Return on assets & 0.08645 & $0.0000^{* * *}$ \\
$X_{7}$ & Government as the largest shareholders & -0.21032 & $0.0000^{* * *}$ \\
Adjusted R-squared $=0.479$ & & \\
\hline
\end{tabular}

* Significant level is $10 \%$; ${ }^{* *}$ Significant level is $5 \%$; ${ }^{* *}$ Significant level is $1 \%$

In addition, returns on assets have significantly positive effect on efficiency value. For the efficient condition of banks utilizing their assets in productive activities, the returns obtained perform on net income after taxes, showing that as the ability of management level in utilizing total assets to create profit get stronger, they can elevate operating efficiency of banks more. Such conclusion is consistent to Lu's (2008) finding in study of analyzing the effect of operating performance in Chiayi Farmers Credit Department in Taiwan, which also has result of positive effect. Government as the largest shareholders appeared to have significantly negative effect on efficiency of state-owned privatization. It showed that if shares held by government are not the largest, there is elevating effect on operating efficiency. Such conclusion is consistent to this study in DEA efficiency value trend analysis of each privatized state-owned banks and showed the same conclusion that efficiency did increase in most state-owned banks after their privatization. The government of Taiwan released their holdings of banks share had positive benefit in promoting privatization to elevate banks' operating efficiency.

Mann-Whiney Non-parametric Examination: In this part the study mainly explored the changing condition of operating efficiency after state-owned banks privatized and used operating efficiency value of foreignowned banks as comparison. Thus, Mann-Whitney non-parametric examination was applied to two sample groups in two periods, consisting of first three years before privatization of each state-owned bank and three years after the privatization.

Table 3: Mann-Whitney Non-parametric Examination Result

\begin{tabular}{lllll}
\hline $\begin{array}{l}\text { Period of } \\
\text { examination }\end{array}$ & Groups of examination & $\begin{array}{l}\text { No. } \\
\text { observation }\end{array}$ & of & Mann-Whitney Examination Result \\
\hline $\begin{array}{l}\text { Before } \\
\text { privatization }\end{array}$ & Domestic banks & 27 & Z Value & P-value \\
& Foreign banks & 21 & -3.589 & 0.0003 \\
\multirow{2}{*}{$\begin{array}{l}\text { After } \\
\text { privatization }\end{array}$} & Domestic banks & 27 & Z Value & P-value \\
& Foreign banks & 21 & 1.140 & 0.2544 \\
\hline
\end{tabular}

Note: Examination period is three years before and after privatization.

From non-parametric examination result in Table 3 we can find that: Before state-owned banks in Taiwan privatized, their group's average efficiency value is significantly lower than that of foreign banks. The $\mathrm{Z}$ value obtained by the two groups in Mann-Whitney examination is -3.589 , which has P-value reaching significant level of 0.0003 under measuring condition of significant level 0.01 . In comparing to examination result after privatization, empirical result show that the difference in average efficiency value between two groups is insignificant. The $\mathrm{Z}$ value obtained in Mann-Whiney examination after privatization is 1.140 , which has Pvalue not reaching significant level of 0.2544 . The result proved the effects that government of Taiwan and private organizations strived for promoting state-owned banks to privatization. The empirical result of this study obtained concrete proof that after state-owned banks become privatized, they have elevated operating efficiency and draw closer to foreign banks in their difference in operating efficiency. 


\section{Conclusion}

The study applied data envelopment analysis method (DEA) to explore changes in efficiency value of every state-owned bank before and after privatization and used empirical non-parametric statistics to analyze the difference between state-owned banks and foreign banks in Taiwan over privatization. Overall, privatization as effect of elevating operating efficiency on state-owned banks, in compliance with the objective of our government in striving for promoting state-owned banks to privatization. For Malmquist productivity index performance of every state-owned bank in cross-periods, Chang Hwa Bank, First Bank, Hwa Han Bank, Farmers Bank, Chiao Tung Bank, Kaohsiung Bank and Taipei Bank, all had growing performance over the six years period, among which productivity of Kaohsiung Bank continued to progress without showing any declining condition. Taipei Bank was the best privatized bank in overall performance, with average Malmquist productivity value of 1.309 . The study result on major factors that affect banks in operating efficiency found that "number of branches" and "return on assets" showed positive relationship to effect on total technical efficiency value. On the other hand, "deposit" and "ratio of government holding" showed negative relationship to effect on total technical value. It represents that government releasing shares through privatization can actually improve banks' operating efficiency, and also through increasing in branches can satisfy people's need and convenience, thus elevating operating efficiency of privatized banks. From Mann-Whitney non-parametric examination results we found: Before state-owned banks in Taiwan privatized, their group's average efficiency value is significantly lower than that of foreign banks. After privatization, there is no significant difference in average efficiency value, proving that operating efficiency of state-owned banks in Taiwan has significantly increased after privatization and that bank privatization policy of the government also receives actual results.

\section{References}

Amemiya, T. (1973). Regression analysis when the dependent variable is truncated normal. Econometric, 41, 997-1016.

Banker, R. D., Charnes, A. \& Cooper, W. W. (1984). Some models for estimating technical and scale inefficiencies in DEA. Management Science, 30, 1078-1092.

Central Bank. (2010). Foreign banks to establish branches in Taiwan. Financial Statistics Monthly, 99(7), 1214.

Charnes, A., Cooper W. W. \& Rhodes, E. (1978). Measuring the efficiency of decision making units. European Journal of Operational Research, 2(6), 429-444.

Cheng, B. T. (2004). Exploration on privatization of state-owned business in U.K., research project, China Petroleum Corporation Refinery and Manufacturing Research Institute.

Cheng, J. A. (2005). A study on the performance evaluation for public-owned bank change to private-owned bank, unpublished master thesis, Department of Applied Economics, National Chung Hsing University.

Chiang, Y. W. (2004). The efficiency analysis of the banks-the case study, unpublished master thesis, Department of International Business, Asia University.

D’Souza, J., Megginson, W. \& Nash, R. (2005). Effect of institutional and firm-specific characteristics on postprivatization performance: Evidence from developed countries. Journal of Corporate finance, 11(5), 747-766.

Drake, L. \& Hall, M. J. B. (2003). Efficiency in Japanese banking: An empirical analysis. Journal of Banking and Finance, 27, 891-917.

Drake, L. \& Howcroft, B. (2002). An insight into the size efficiency of a UK bank branch network. Managerial Finance, 28(9), 24-36.

Goldberger, A. S. (1964). Econometric Theory, New York: Wiley.

Hu, W. C., Lai, M. C. \& Huang, H. C. (2009). Rating the relative efficiency of financial holding companies in an emerging economy: A multiple DEA approach. Expert Systems with Applications, 36(3), 5592-5599.

Lin, M. Y. (2003). Study on operating efficiency of privatized state-owned banks in Taiwan region-application of DEA method, unpublished master thesis, Department of Business Administration, National Cheng Kung University.

Lu, Y. H. (2008). An analysis of the efficiency on the credit department of farmer's association in Chiayi County, unpublished master thesis, Institute of Financial Management, Nanhua University. 
Mahboobi, L. (2000). Recent privatization trends. Financial Market Trends, 76(5), 43-65.

Martin, S. \& Parker, D. (1995). Privatization and economic performance throughout the UK business. Managerial and Decision Economics, 16, 225-237.

Mostafa, M. (2007). Benchmarking top Arab banks' efficient frontier analysis. Industrial Management and Data Systems, 107(6), 802-823.

Sathye, M. (2001). X-efficiency in Australian banking: An empirical investigation. Journal of Banking and Finance, 25, 613-630.

Sherman, H. D. \& Gold, F. (1985). Bank branch operating efficiency: Evaluation with DEA. Journal of Banking and Finance, 9, 297-315.

Sueyoshi, T. (1998). Privatization of Nippon telegraph and telephone: Was it a good policy decision? European Journal of Operational Research, 107(1), 45-61.

Teng, J. Y. (2002). Experience and inspiration of opening up establishment of private banks-competition faced by private banks in Taiwan, National Policy Foundation Research Report.

Tobin, J. (1958). Estimation of relationships for limited dependent variables. Econometric, 26, 24-36.

Tsamenyi, M., Onumah, J. \& Tetteh-Kumah, L. (2010). Post-privatization performance and organizational changes: Case studies from Ghana. Critical Perspectives on Accounting, 21(5), 428-442.

Uddin, S. \& Hopper, T. (2003). Accounting for privatization in Bangladesh: Testing Word Bank claims. Critical Perspectives on Accounting, 14(7), 739-774.

Wei, Z., Varela, O., D'Souza, J. \& Hassan, M. K. (2003). The financial and operating performance of China's newly privatized firm. Financial Management, 32(2), 107-126.

Wu, S. L., Sung, C. L., Hong, D. S. \& Lee, C. S. (2004). Study on changes in performance before and after stateowned business in Taiwan became privatized. Taiwan Banks Quarterly, 55 (2), 69-88.

Yarrow, G. (1986). Privatization in theory and practice. Economic Policy, 1(2), 323-337. 